\title{
Physical and ecological processes at a moving ice edge in the Fram Strait as observed with an AUV
}

\author{
Thorben Wulff*, Eduard Bauerfeind, Wilken-Jon von Appen \\ Alfred Wegener Institute Helmholtz Centre for Polar and Marine Research, Am Handelshafen 12, 27570 Bremerhaven, Germany
}

\section{A R T I C L E I N F O}

\section{Article history:}

Received 4 October 2015

Received in revised form

22 March 2016

Accepted 4 July 2016

Available online 5 July 2016

Keywords:

Physical-biological coupling

Biogeochemistry

Marginal ice zone

AUV

Front

Fram Strait

\begin{abstract}
A B S T R A C T
Small-scale investigations of physical and biogeochemical parameters have been carried out with an autonomous underwater vehicle (AUV) at a moving ice edge in the Fram Strait. The AUV was equipped with various sensors to study the complex interactions between physical and ecological processes along the ice edge and the associated meltwater front. The AUV covered two cross-front sections of $9 \mathrm{~km}$ and recorded high resolution vertical profiles of the physical and biogeochemical properties between 0 and $50 \mathrm{~m}$ water depth at a horizontal station spacing of 800-1000 m.

In both physical and biogeochemical terms, the measurements revealed a complex structure of the water column. The distribution of phytoplankton biomass (chlorophyll $a$ ) and nutrients was highly inhomogeneous. Chlorophyll $a$ concentrations of $5 \mu \mathrm{g} \mathrm{l}^{-1}$ were detected at the frontal interface in a small corridor just 2-4 km wide and only $5 \mathrm{~m}$ deep. Nutrients at the surface were depleted, yet, compared to previous studies of this region, were still present in the euphotic zone. Below the euphotic zone, nitrate concentrations of $8 \mu \mathrm{mol} \mathrm{l}^{-1}$ and oxygen saturation values of $100 \%$ resulted in a "dome-like" pattern suggestive of vertical transport processes. Based on these measurements, three different zones featuring individual biogeochemical characteristics were identified in the cross-front sections. Atmospheric forcing and the presence of the melt water front are assumed to be mainly responsible for the complexity of the water column. Localized vertical transport events seem to have occurred before our investigations. Furthermore, wind driven frontogenesis likely contributed to vertical water movements. All processes had an effect on the biological processes along the observed meltwater front.
\end{abstract}

(c) 2016 Elsevier Ltd. All rights reserved.

\section{Introduction}

It is well known that ice plays a key role in shaping Polar marine ecological systems and that the Marginal Ice Zone (MIZ) in particular promotes phytoplankton blooms and enhanced biological productivity (e.g. Smith et al., 1985; Perrette et al., 2011). The pronounced stratification, caused by fresh water from melting sea ice, prevents deep mixing, keeping phytoplankton in the euphotic zone (Niebauer and Alexander, 1985; Doney, 2006) and leading to prolonged phytoplankton blooms that are only terminated by nutrient depletion. However, filaments, eddies or other dynamic transport and mixing processes are common features in the water column of MIZs (Engelsen et al., 2002). Atmospheric forcing adds further complexity and the interaction between ocean, ice and atmosphere creates an extremely dynamic environment in both physical and ecological terms (Wassmann and Reigstad, 2011; Cherkasheva et al., 2014). Apart from these regional effects, the

\footnotetext{
* Corresponding author.

E-mail address: thorben.wulff@awi.de (T. Wulff).
}

world's Polar ice coverage is rapidly changing due to climate change - with consequences for the ecological system which are only partly understood. Against this background, understanding physical processes in the MIZ and bridging the gap to the associated ecological response is crucial to predict the conditions of the Polar Oceans in the future.

In the Arctic, the Fram Strait is a region that exhibits particularly dynamic interactions between the ocean and sea-ice. The Fram Strait features bathymetric anomalies, such as the Molloy Deep (5607 m, Thiede et al., 1990), and complex hydrography. The hydrographic regime is dominated by the warm, northward flowing West Spitsbergen Current (WSC) in the east (BeszczynskaMöller et al., 2012) and the cold, southward flowing East Greenland Current (EGC) in the western Fram Strait (de Steur et al., 2009). The Fram Strait is also the major route for Arctic sea-ice export. Roughly $10 \%$ of the Arctic sea-ice cover leaves the central Arctic via this strait every year (Kwok et al., 2009). Due to the close proximity to the warm WSC, the sea-ice transported by the EGC encounters year-round melting processes sustaining a meltwater front. 
Frontal systems can comprise complex hydrographic structures such as Kelvin-Helmholtz instabilities and geostrophic and ageostrophic circulations. Atmospheric forcing can stimulate front related transport processes. For example, as a result of wind driven ageostrophic secondary circulations (ASC), Thomas and Lee (2005) were able to simulate and detect strong up- and downwelling along frontal systems associated with symmetric instability (SI, Haine and Marshall, 1998; Thomas et al., 2013).

Phytoplankton growth is stimulated by upper water column processes at the MIZ as it is dependent on the availability of sunlight. However, the remoteness of MIZs, harsh environmental conditions and fluctuating dynamics make it difficult to achieve on-site observations in surface waters. "Traditional" shipboard measurements might not necessarily represent true environmental conditions as the presence of a research vessel disturbs the delicate stratification of the upper water column. As a consequence, in order to better understand the interaction between physics and phytoplankton ecology in the MIZ, new technologies need to be applied. Modern instruments such as gliders and autonomous underwater vehicles (AUVs) represent suitable platforms to meet the requirement of conducting high resolution synoptic measurements with minimal disturbance (Lee et al., 2012; Zhang et al., 2013, 2015). Recently, for example, gliders were used to study the MIZ in the Beaufort Sea as part of the Marginal Ice Zone Program of the Office of Naval Research (ONR) (Lee et al., 2012).

In the framework of the project "HAUSGARTEN", the Alfred Wegener Institute Helmholtz Centre for Polar and Marine Research (AWI) in Bremerhaven, Germany, has conducted year-round investigations on the pelagic-benthic coupling in seasonal ice covered areas of the Fram Strait by means of moored instruments since 1999 (e.g. Bauerfeind et al., 2009). As part of this project AWI 's AUV "PAUL", which is equipped with physical and biogeochemical sensors, has been deployed several times. PAUL's operations are specifically designed to study the near-surface part of the water column. The study presented here focuses on one of PAUL's dives which took place at the periphery of a large ice tongue in the Fram Strait in summer 2013. The vehicle's deployment particularly focused on investigating physical processes along the ice tongue's meltwater front in high spatial resolution and to understand the ecological response. The dive was intended to resolve the water column structure of the euphotic zone. Simultaneous measurements of the wind conditions support the interpretation of the AUV data within the context of a meltwater front under atmospheric forcing. To our knowledge this is the first study presenting results from such an environment at high spatial resolution.

\section{Methods and data}

\subsection{AUV "PAUL“}

PAUL is based on a type 21 vehicle of the American manufacturer Bluefin Robotics (Quincy, Massachusetts, USA). The torpedo-shaped vehicle is $4.3 \mathrm{~m}$ long, weighs approx. $400 \mathrm{~kg}$ and has an operational range of $70 \mathrm{~km}$. Considering its intended mission types, namely shallow missions, the original depth rating of $3000 \mathrm{~m}$ was limited to $600 \mathrm{~m}$. Since 2009, PAUL has regularly operated in the MIZ of the Fram Strait (Wulff et al., 2013). During the 2013 Arctic campaign, PAUL's scientific payload consisted of different sensors and a water sample collector (Table 1).

For this particular campaign, the water samples were only used to calibrate the nitrate sensor and to convert the analog signals of the C7-c fluorometer to chlorophyll $a$ concentrations (Wulff et al., 2013). To determine nitrate concentrations, $8 \mathrm{ml}$ of each water sample was stored at $-20^{\circ} \mathrm{C}$ and later measured colorimetrically using a QuAAtro SFA Analyzer (Seal Analytical, Southampton, UK). After the subsample was taken for nitrate analysis, the rest of each sample ( $\sim 180 \mathrm{ml}$ ) was filtered onto Whatman GF/F filters ( $25 \mathrm{~mm}$ diameter, $0.7 \mu \mathrm{m}$ nominal pore size) to determine chlorophyll $a$ concentrations. The filters were stored at $-20{ }^{\circ} \mathrm{C}$, until treatment by an ultrasonic device and chlorophyll $a$ extraction into $90 \%$ acetone. Chlorophyll $a$ content of this solution was measured with a calibrated TD-700 Laboratory Fluorometer (Turner Designs, Sunnyvale, California, USA) (Edler, 1979; Evans et al., 1987).

Table 1

Scientific instruments of PAUL in the 2013 Arctic campaign.

\begin{tabular}{lll}
\hline Parameter & Type of device & Manufacturer \\
Conductivity & & \\
Temperature & SBE 49 FastCAT & Sea Bird Electronics (Bellevue, Washington, USA) \\
Pressure & & \\
Dissolved Oxygen & SBE 43 & Sea Bird Electronics (Bellevue, Washington, USA) \\
Nitrate & Deep SUNA & Satlantic (Halifax, Canada) \\
Irradiance (PAR) & PAR-log-s & Satlantic (Halifax, Canada) \\
Chlorophyll a & C7-c & Turner Designs (Sunnyvale, California, USA) \\
CDOM & C7-u & Turner Designs (Sunnyvale, California, USA) \\
pCO ${ }_{2}$ & HydroC CO2 & Contros (Kiel, Germany) \\
Sample Collector & Prototype & AWI
\end{tabular}



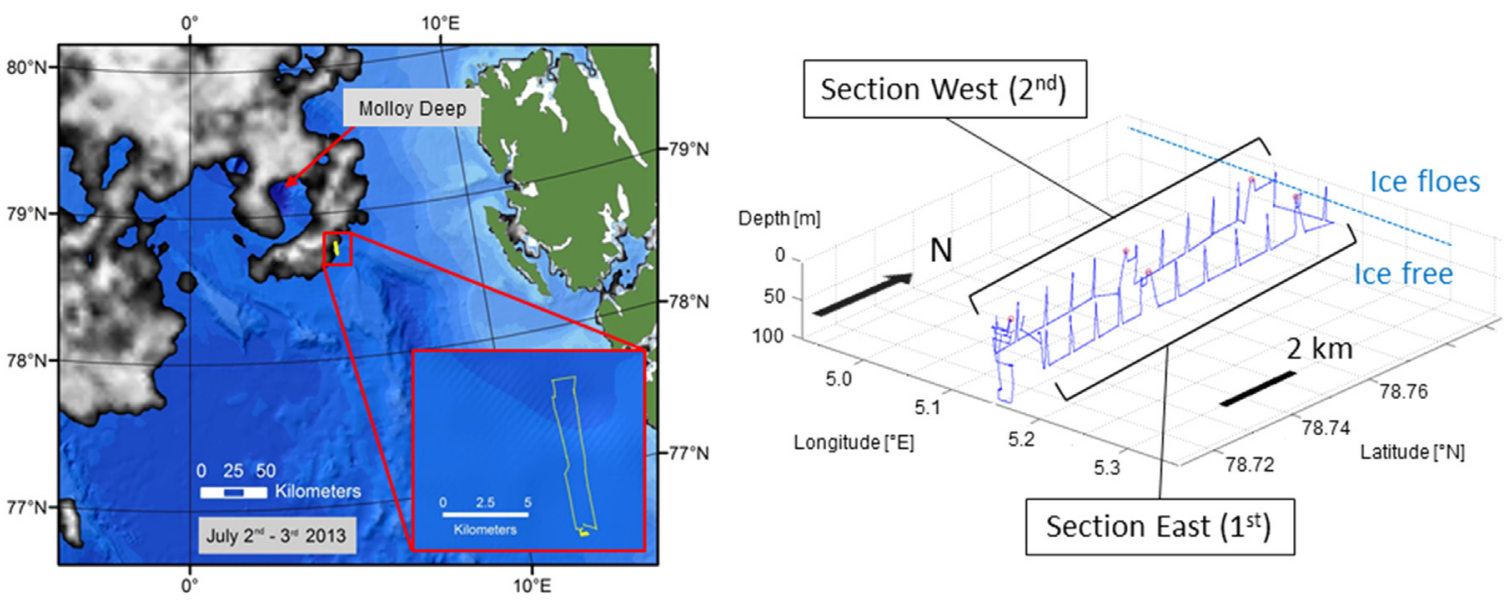

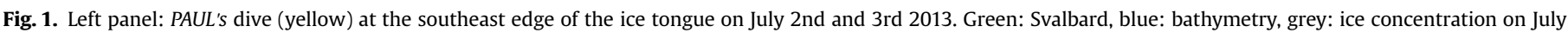

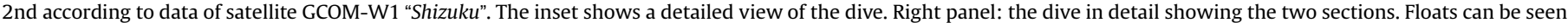

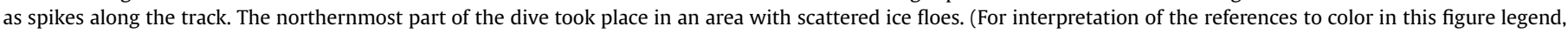
the reader is referred to the web version of this article.)

\subsection{AUV Operations}

PAUL was deployed by the German research vessel "Maria $S$. Merian" (in further text: "Merian") as part of the Arctic expedition MSM 29 in 2013 (Wenzhöfer et al., 2014). The 6-h dive that this study focusses on, the third of the expedition, started on July 2nd at 2030 UTC.

The dive area was localized from satellite imagery and an observation of the evolution of the sea-ice cover. On a smaller scale, the dive area was further localized using temperature, salinity and fluorescence recordings obtained by Merian's underway measurement system. Navigating relative to the ice edge, Merian could determine the position and orientation of the meltwater front which PAUL was supposed to cross during the mission.

The dive area was situated close to the Molloy Deep at $78.76^{\circ} \mathrm{N}$, $5.15^{\circ} \mathrm{E}$ at the southeast edge of a large ice tongue (Fig. 1). The mission itself consisted of two $9 \mathrm{~km}$ sections perpendicular to the meltwater front. The two sections were $\sim 1 \mathrm{~km}$ apart, with the eastern section being the first to be occupied by PAUL. Along the sections, PAUL conducted several "float" maneuvers where it shut down its thruster, drifted towards the surface with $10-20 \mathrm{~cm} \mathrm{~s}^{-1}$ vertical speed and recorded a high resolution vertical profile of the water column (Wulff et al., 2013). Each float started at $50 \mathrm{~m}$ water depth. In open water, PAUL reactivated its thruster at $3 \mathrm{~m}$ water depth, still drifting further up to $1 \mathrm{~m}$ below the surface. If there was the risk of encountering ice floes, the thruster was reactivated at $7 \mathrm{~m}$ depth, with PAUL ascending to a depth of $5 \mathrm{~m}$. In total, 22 floats were conducted during the entire mission, resulting in a horizontal station spacing of $800-1000 \mathrm{~m}$ (Fig. 1). Between the floats, the AUV travelled at $50 \mathrm{~m}$ depth which is below the area that this study focuses on. Therefore, we only present data recorded during the floats.

In order to accurately georeference the measurements, PAUL's navigation data needed to be corrected. Due to the nature of shallow AUV missions at the Molloy Deep area occurring thousands of meters above the seafloor, the vehicle's Doppler velocity log was unable to establish seafloor tracking, resulting in no fixed reference to support the inertial navigation system and the navigation accuracy was degraded. Consequently, the ultra-short baseline system "GAPS", of the French manufacturer iXBlue, (Marly le Roi, France) was used to track the vehicle from the ship. After the dive, PAUL's navigation data were corrected applying GAPS tracking data and the correction algorithm described by Wulff and Wulff (2015).

\subsection{Environmental data}

\subsubsection{Ice cover from satellite data}

The dynamics of the ice was monitored using data of the Advanced Microwave Scanning Radiometer 2 (AMSR2) instrument onboard the Japanese earth observation satellite GCOM-W1 "Shi$z u k u$ ". Data were processed by the Institute of Environmental Physics at the University of Bremen (Bremen, Germany). Derived ice charts have a spatial resolution of $3.125 \mathrm{~km}$ and a temporal resolution of $24 \mathrm{~h}$ (Spreen et al., 2008). The ice edge was defined as the $10 \%$ ice concentration boundary line. The link to the applied dataset is given in the acknowledgements.

\subsubsection{Salinity, Temperature and Chlorophyll a from Merian's un- derway system}

A shipboard thermometer (SBE 38), a thermosalinograph (SBE 45) (both manufactured by Sea Bird Electronics), and an ECO FLNTU fluorometer (WetLabs Philomath, Oregon, USA) were used to permanently collect environmental data as Merian was travelling. The water inlet of the system was positioned $\sim 6 \mathrm{~m}$ below the water line.

\subsubsection{Wind data from a reanalysis}

Velocity and direction of the wind was determined using model data of the Modern-Era Retrospective Analysis for Research and Applications (MERRA) (Rienecker et al., 2011) as provided by the GIOVANNI platform (Acker and Leptoukh, 2007). The spatial resolution of the data is $1.25^{\circ} \times 1.25^{\circ}$ and the temporal resolution is $3 \mathrm{~h}$. Since the surface wind speed is of interest for this study, only the $1000 \mathrm{hPa}$ pressure level was analyzed. The link to the applied dataset is given in the acknowledgements.

Shipboard wind measurements served as reference values to allow a ground truthing of the MERRA data. From 63 comparative measurements carried out between June 25th and July 3rd, 2013, 52 wind direction measurements $(82 \%)$ were within a tolerance limit of $\pm 30^{\circ}$ and $49^{\circ}$ wind speed measurements (78\%) were within a tolerance limit of $\pm 2 \mathrm{~m} \mathrm{~s}^{-1}$. The local wind conditions in the study area were determined by averaging the velocities and directions of the four MERRA grid points bordering PAUL's area of operation. In this study, the wind direction is given in relation to the ice edge or the meltwater front respectively (Fig. 2).

The depth of the wind-influenced layer depends on the turbulence level and type in the upper water column, which is typically parameterized by an eddy viscosity $A_{z}$. The thickness of the 

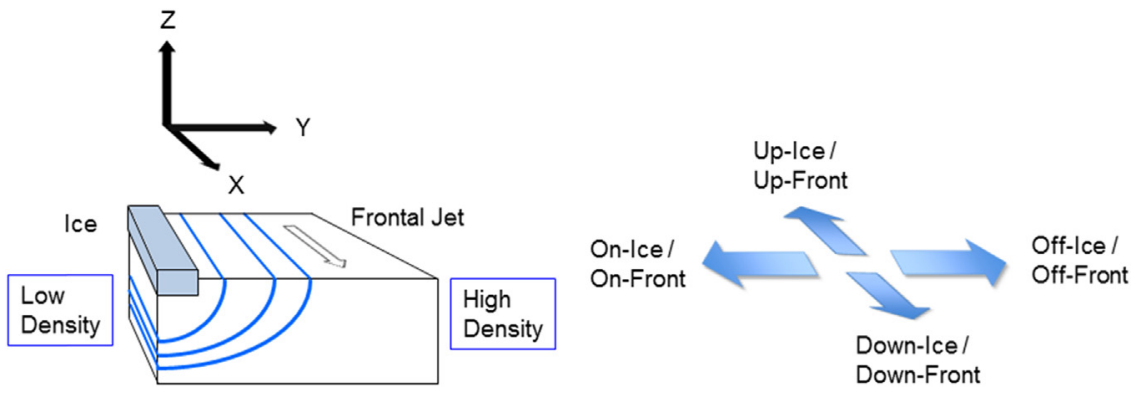

Fig. 2. Naming convention to define orientations and directions for this study.

Ekman layer (Ekman, 1905) can then be expressed as:

$D_{E}=\sqrt{\frac{2 \pi^{2} \cdot A_{Z}}{\bar{\rho}_{D} \bullet f}}$

Here, $\bar{\rho}_{D}$ is the average potential density of a water body and $f$ is the Coriolis parameter.

\subsubsection{Surface irradiance}

Surface irradiance $E$ in the wavelength range of $400-700 \mathrm{~nm}$ (photosynthetically active radiation, PAR) was constantly measured with a shipboard radiometer. By comparing these surface data with PAUL's irradiance data, the euphotic depth (ED) could be determined. Conventionally the threshold value to define the lower boundary of the euphotic zone is set at the depth where $1 \%$ of the surface irradiance value is still present (e.g. Lee et al., 2007).

\section{Results and discussion}

\subsection{Physical conditions in the MIZ}

Before turning our attention to the sections measured by the AUV, we first describe the physical conditions at the dive site from auxiliary data.

\subsubsection{Environmental data}

Environmental data considered in this study date back one week prior to the dive. To provide a coherent picture of the measurements and to bring them into temporal focus, data are contextualized in a single figure (Fig. 3). PAUL's dive on July 2nd is marked on the timeline of (Fig. 3a).

3.1.1.1. Ice cover. From June 25th onwards, an ice tongue extended southwards from the main ice edge south of the Molloy Deep area

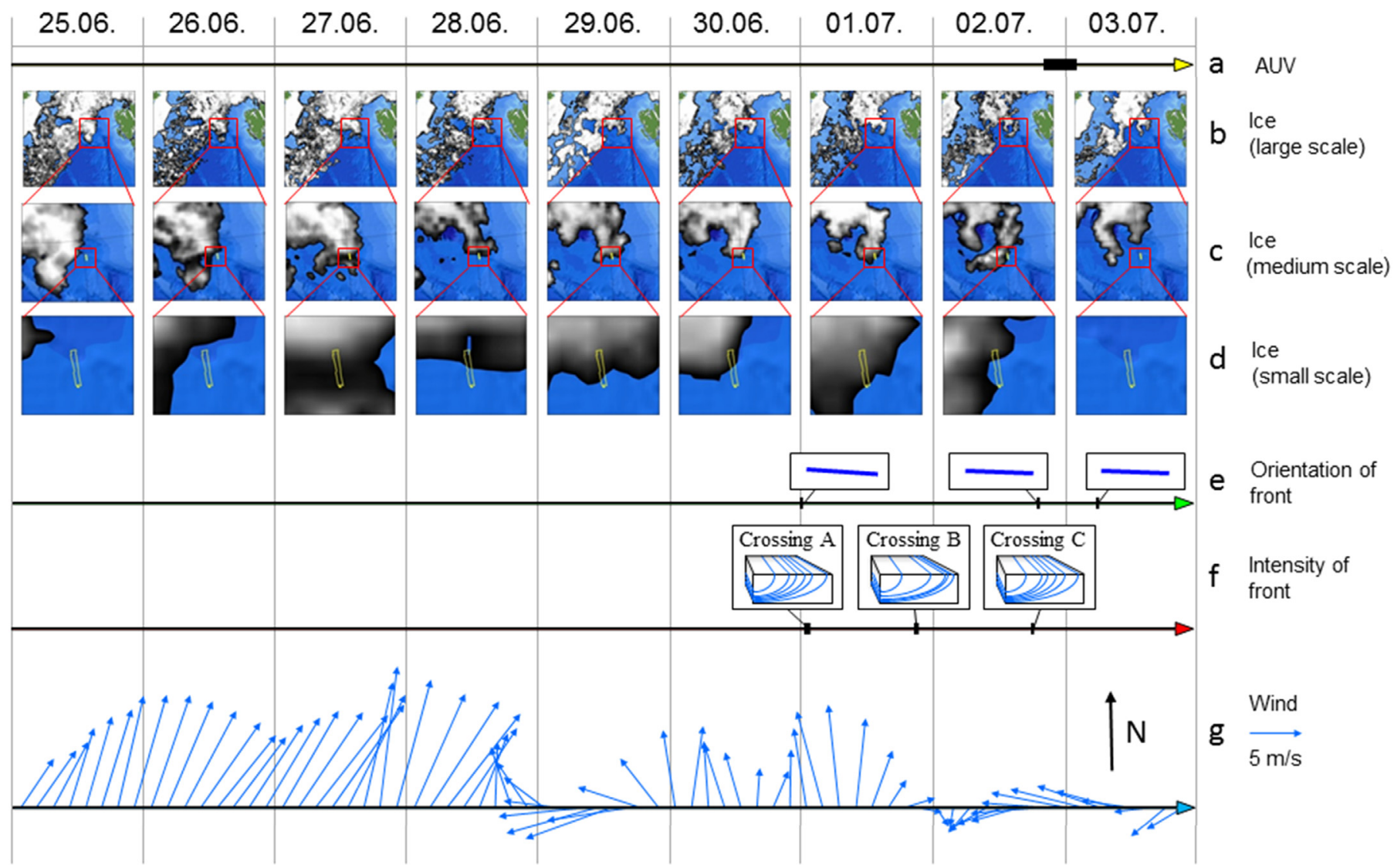

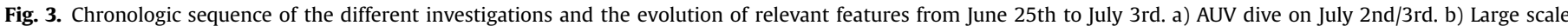

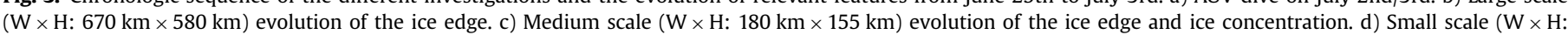

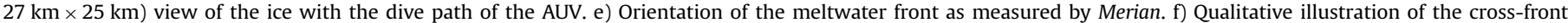
density gradient (intensity of front) as measured by Merian. g) Wind speed and direction. 
(Fig. 3b, c, d). Between June 25th and June 28th this ice tongue drifted to the northeast with the southern tip of the ice tongue travelling $70 \mathrm{~km}$ in $72 \mathrm{~h}$. After this period, the ice tongue remained at its geographical site, yet changed its shape. Between June 28th and June 29th a second and smaller ice tongue emerges just to the west of the Molloy Deep. The Molloy Deep itself remained ice free. Over the following days both tongues slowly advanced to the south. On July 2nd the tongue in the east suddenly drifted several kilometers to the southwest, so both tongues formed an almost closed ring around the Molloy Deep. On this particular day, PAUL was deployed at the southeast edge of the eastern tongue. On the day after the dive the eastern tongue abruptly retreated several kilometers northward. In contrast to that, the western tongue kept drifting southward. Merian's radar systems indicated that the ice field at PAUL's study area consisted of numerous ice floes of different sizes and with different surface textures.

3.1.1.2. Meltwater front. The formation of a meltwater front was associated with the ice edge. Beginning on June 25th, the front was crossed several times by Merian and on July 1st, 2nd and 3rd the orientation of the front was determined by crossing it within short periods of time at different locations. The front stretched from east to west with the meltwater in the north (Fig. 3e). On July 2nd and 3rd the front was crossed 6 times within $12 \mathrm{~h}$. In this time the front drifted $\sim 1.1 \mathrm{~km}$ northward.

Data of three different cross-front sections (Crossing A, B and C, Fig. 4), which were occupied by Merian on July 1st and 2nd, revealed differences in the intensity of the front. Data of crossings A and $\mathrm{C}$ showed a relatively smooth transition between Atlantic water and meltwater. In contrast, a sharp bend can be noticed in the temperature and salinity graphs of crossing B (at $3 \mathrm{~km}$ ) and the graph is curved in a convex manner. This can be interpreted as a strong horizontal gradient with contour lines on the surface lying closer to each other than in crossings A and C (Fig. 3f).

3.1.1.3. Wind and Surface Irradiance. The investigated time frame was dominated by southerly or southwesterly winds (Fig. 3g). Short phases of easterly winds were only observed on June 29th, July 2nd and July 3rd. For these easterly wind events, the average wind speed was $5.5 \mathrm{~m} \mathrm{~s}^{-1}$ ( $\max .8 .7 \mathrm{~m} \mathrm{~s}^{-1}$, $\min 1.8 \mathrm{~m} \mathrm{~s}^{-1}$ ). For the rest of the time the average wind speed was $8.5 \mathrm{~m} \mathrm{~s}^{-1}$ (max. $13.6 \mathrm{~m} \mathrm{~s}^{-1}$, min. $2.1 \mathrm{~m} \mathrm{~s}^{-1}$ ).

An Ekman layer of $70 \mathrm{~m}$ depth would result from an eddy viscosity of approximately $40 \mathrm{~kg} \mathrm{~m}^{-1} \mathrm{~s}^{-1}$ which is similar to what has been inferred (Schmidt, 1917; Neumann and Pierson, 1966) for wind velocities of $\sim 9 \mathrm{~m} \mathrm{~s}^{-1}$. This wind velocity is consistent with values recorded during the investigated time frame. Due to lower wind speeds during the easterly wind events, the Ekman layer may have been shallower $(40 \mathrm{~m})$ during these events.

For the time of the dive, the average irradiance level at the surface was $156 \mu \mathrm{mol} \mathrm{m}^{-2} \mathrm{~s}^{-1}$ with a maximum value of $616 \mu \mathrm{mol} \mathrm{m}^{-2} \mathrm{~s}^{-1}$ and a minimum value of $47 \mu \mathrm{mol} \mathrm{m} \mathrm{m}^{-2} \mathrm{~s}^{-1}$.

\subsubsection{AUV sections}

PAUL was deployed at approximately $5 \mathrm{~km}$ distance to the iceassociated meltwater front. As measured by PAUL, the meltwater
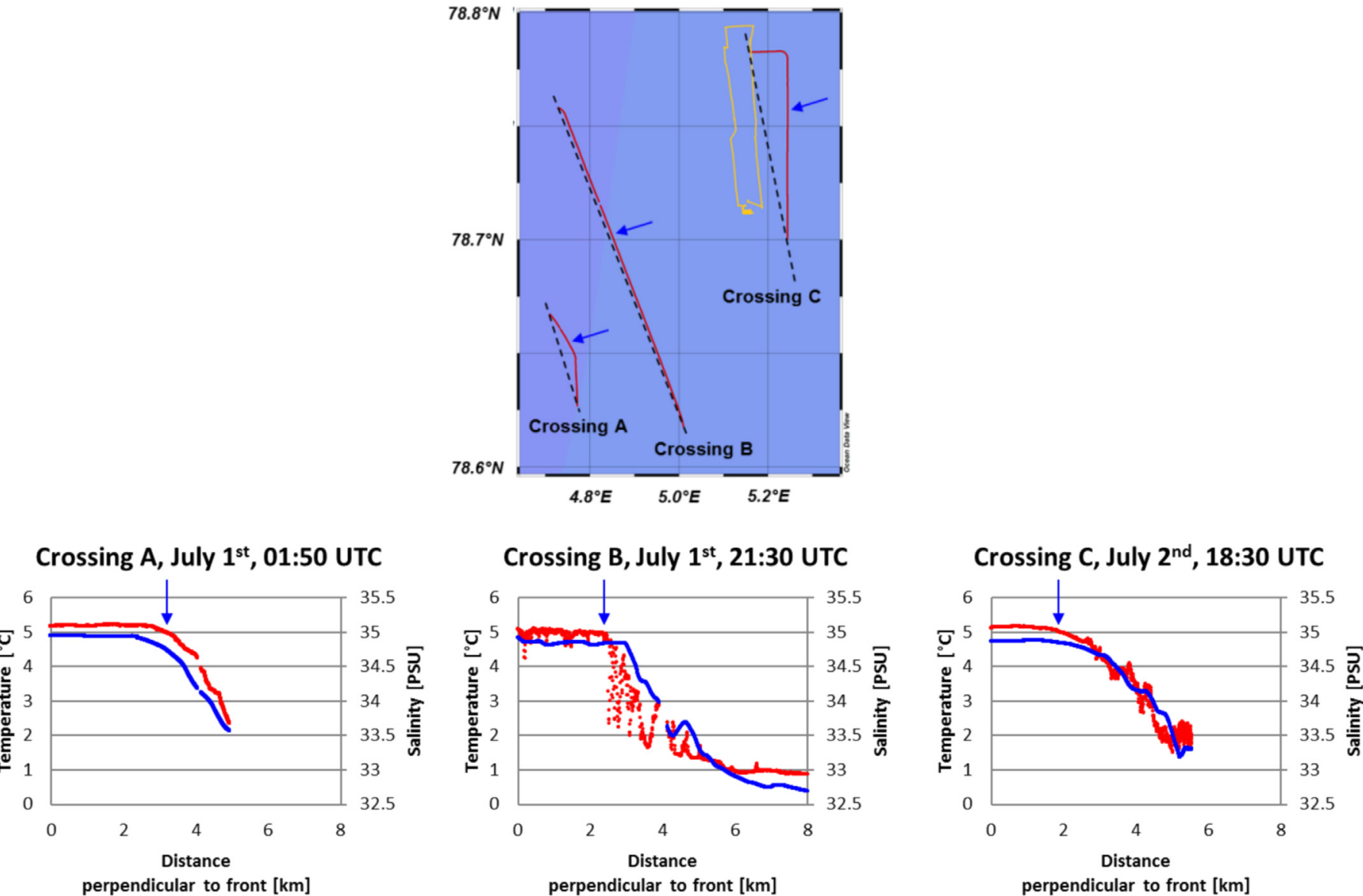

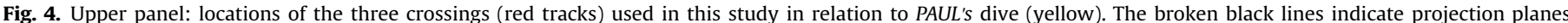

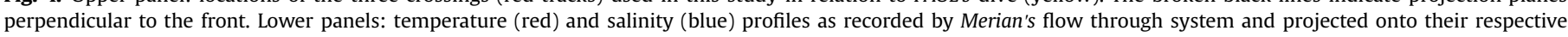

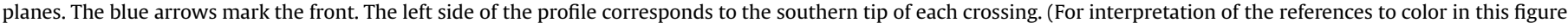
legend, the reader is referred to the web version of this article.) 


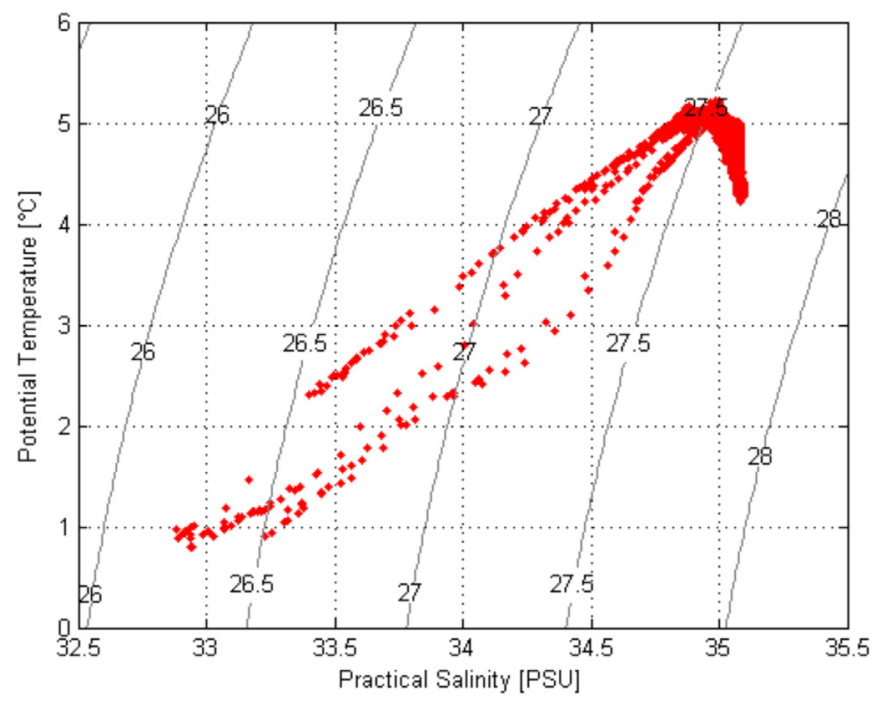

Fig. 5. T-S diagram of the AUV data showing physical properties of the investigated water masses. Grey contour lines represent isopycnals. Values conglomerate at a salinity of about 35 and $4.2-5.3{ }^{\circ} \mathrm{C}$. Modified Atlantic water representing the meltwater layer is visible at salinities below 35 .

layer consisted of modified Atlantic water, featuring lower temperatures and salinities compared to the Atlantic water masses below. The Atlantic water masses had an average salinity of $\sim 35$ and temperature of $4.2-5.3{ }^{\circ} \mathrm{C}$. In the meltwater layer itself, water temperatures dropped below $1{ }^{\circ} \mathrm{C}$ and salinity values reached a minimum of 33 (Fig. 5).

Beginning at a section distance of $x=6 \mathrm{~km}$ in the AUV transect (Fig. 6), the meltwater layer can be seen as a water body of $15 \mathrm{~m}$ thickness. Isopycnals around the meltwater layer run close to each other and show the strong stratification of the water column in this area. An area at around $x=2 \mathrm{~km}$ and $25-30 \mathrm{~m}$ water depth is noticeable as isopycnals have an increased vertical separation and the water column is less stratified from the surface to $50 \mathrm{~m}$ water depth (Fig. 6c). Other areas with low buoyancy frequencies can be recognized at $x=6-8 \mathrm{~km}$ and $x=4-6 \mathrm{~km}$ in the west and east sections respectively. However, these only reach to $30 \mathrm{~m}$ and not to the surface.

The meltwater front, indicated by isopycnals of $27.6 \mathrm{~kg} \mathrm{~m}^{-3}$ and below, exhibits steep horizontal gradients and therefore is likely subject to fast instabilities, such as symmetric instability (Thomas et al., 2013). Away from the front, the water column is stable with respect to symmetric instability.

Except for minor variations, the two sections are qualitatively similar in their hydrographic structures.

\subsection{Physical Processes in the MIZ}

There are two paradigms in which one can interpret the situation at the meltwater front sampled by the AUV. The observations only resolve the meltwater front at two locations in the along-front direction separated by about $1 \mathrm{~km}$ and $6 \mathrm{~h}$ at the southern end. These two observations are qualitatively and quantitatively very similar to each other (Figs. 6 and 8) suggesting that the along-front gradient is small over the sampled distance. It may be small because of one of the following scenarios: (1) there is no actual along-front gradient even on larger scales, (2) the along-front distance scale over which properties significantly change is larger than the separation between the measurements, or (3) there is vast variability in the along-front direction, perhaps even on scales smaller than the distance between the two measurements and the fact that there is high qualitative and quantitative agreement is pure coincidence. We reject option (3) here as it appears unlikely and measurements from other years (2012 and 2015, unpublished data) concur with our findings over similar horizontal distances.

Fronts that turn unstable generate variability in the along-front direction with a typical wavelength. For mesoscale instabilities, that scale is the Rossby radius and for submesoscale motions it is the mixed layer radius (Thomas, 2008).

$R_{M L}=\frac{N_{M L} \cdot h_{M L}}{f}$

Typical values from the observations on the less stratified side of the front (Fig. 6c) show the mixed layer to reach $40 \mathrm{~m}$ deep and have an average stratification of $10^{-2} \mathrm{~s}^{-1}$, resulting in a mixed layer radius of about $2.8 \mathrm{~km}$. The time scale of the motions would be approximately $2 \pi / f$ or $12 \mathrm{~h}$. Hence the spatial and temporal scale of the variability is larger than the separation of the two sections of the AUV dive.

Instabilities at fronts grow and can produce eddies, which may shed and propagate away from the front. Meanwhile, they would carry water properties from both sides of the front in the eddy. It is conceivable that the AUV section cut across one or two such submesoscale eddies which had propagated away from the front. This might explain the large biogeochemical property changes over scales of $2-3 \mathrm{~km}$, especially in the deeper part of the section south of the meltwater layer. However, the physical data does not show the cold fresh meltwater signature at section distances of less than $6 \mathrm{~km}$ (Fig. 6a, b). This suggests that the AUV section did not cut across submesoscale eddies (scenario 2). Therefore, we explain the distribution of the biogeochemical properties by dynamics that can also be present when the along-front gradients are much smaller than the cross-front gradients (scenario 1 ).

\subsubsection{Frontogenesis}

Most studies investigating physical processes initiated by atmospheric forcing have focused on the influence of the ice itself. Apart from the ice edge however, frontal systems can also generate vertical transports and therefore need to be taken into account as well. As it was shown along the Kuroshio Current (Thomas and Lee, 2005; Clayton et al., 2014) or the Gulf Stream (Thomas et al., 2013), down-front wind conditions can cause an intensification of a front (frontogenesis). Frontogenesis is a stepwise process that involves the generation of ageostrophic secondary circulations (ASC) with downwelling on the dense side of the front and upwelling along the frontal interface (Thomas and Lee, 2005). The characteristic cross-front width of an ASC is defined as the distance between the upwelling or downwelling branches of two neighboring circulating cells ( $L_{0}$, Thomas and Lee, 2005).

$L_{0}=\frac{4 H}{f^{2}} \sqrt{\frac{g}{\rho_{0}}\left(\frac{\partial \rho}{\partial z} f^{2}+\left(\frac{\partial \rho}{\partial y}\right)^{2}\right)}$

Here, $H$ is the depth of the mixed layer, $f$ is the Coriolis parameter and $\partial \rho / \partial z$ and $\partial \rho / \partial z$ represent the vertical and horizontal (cross-front) density gradients respectively.

In our study, the structure of the water column close to the meltwater front indicates the presence of ongoing upwelling and downwelling processes. Isopycnals bulge upwards at section distances of $x=5-6 \mathrm{~km}$ and $7-8 \mathrm{~km}$ (section west) and at $x=4-5 \mathrm{~km}$ and $7 \mathrm{~km}$ (section east) (Fig. 7).

In this region, the water column structure suggests a horizontal density gradient of $\sim 4 \cdot 10^{-4} \mathrm{~kg} \mathrm{~m}^{-3} \mathrm{~m}^{-1}$ and a vertical gradient of $\sim 7 \cdot 10^{-2} \mathrm{~kg} \mathrm{~m}^{-3} \mathrm{~m}^{-1}$ along the sections shown in Fig. 7. Applying these values and assuming a mixed layer depth of $30 \mathrm{~m}$ and a reference layer density of $1027 \mathrm{~kg} \mathrm{~m}^{-3}$ in Eq. (3), leads to a cross front width of the ASC of $2-6 \mathrm{~km}$, which is consistent with the 

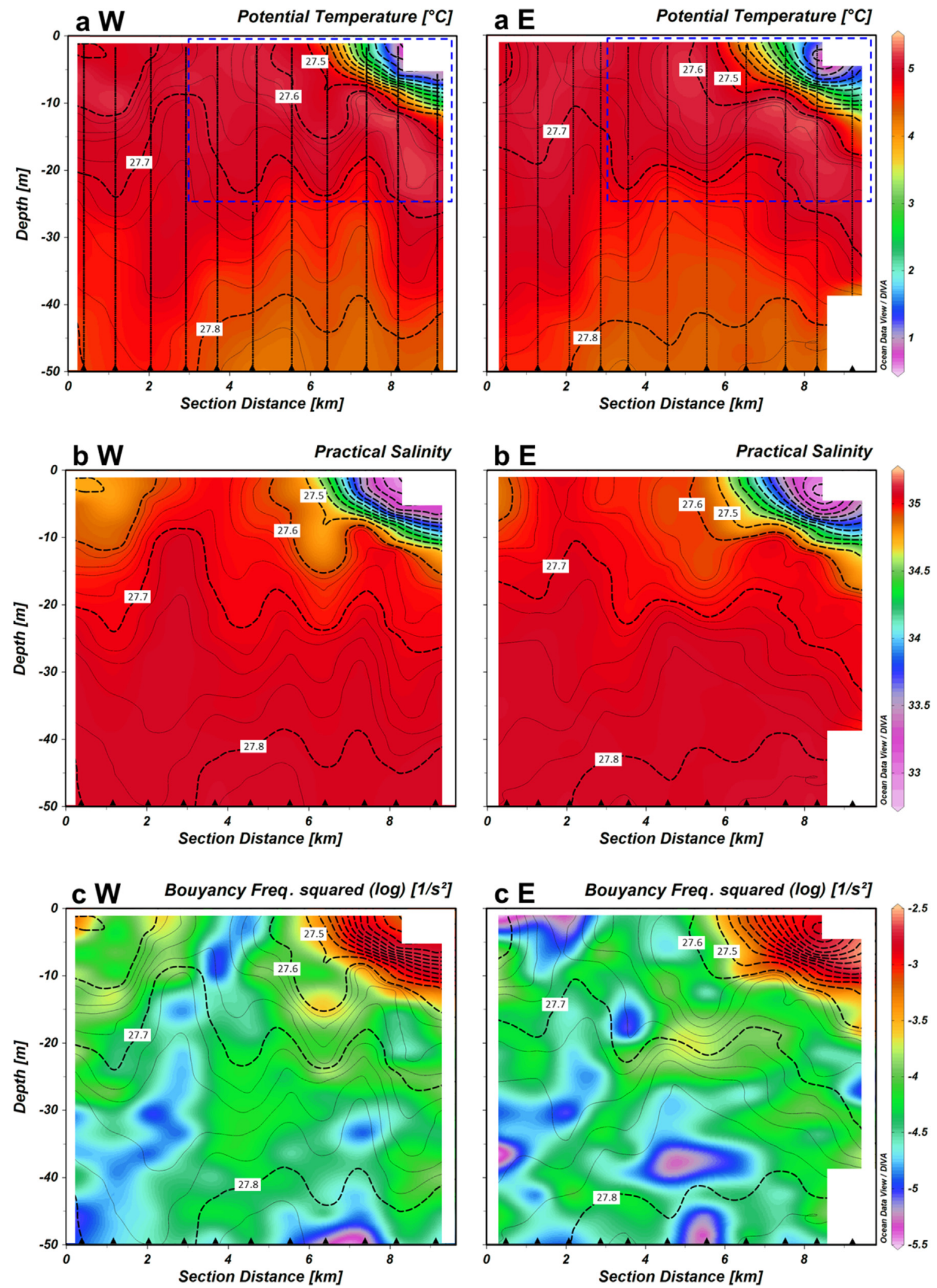

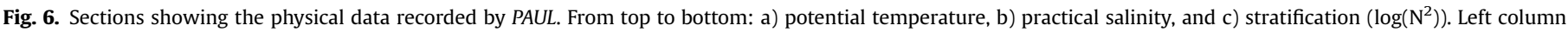
shows results for section west (W), right column for section east (E) (Compare Fig. 1). A section distance of $\boldsymbol{x}=0 \mathrm{~km}$ corresponds to the southern (ice free) end of the sections. Figures aW/aE and bW/bE contain the following isopycnals: Broken black lines represent an increment of $0.1 \mathrm{~kg} \mathrm{~m}^{-3}$. For $\sigma_{\theta}>27.6 \mathrm{~kg} \mathrm{~m}^{-3}$, an increment of $0.02 \mathrm{~kg} \mathrm{~m}{ }^{-3}$ is indicated by thin black lines. Black triangles at the bottom of each section show positions of the float maneuver (additionally illustrated by vertical lines in the potential temperature plot). The broken blue rectangle in the potential temperature plot depicts the boundaries of a detail view used in Fig. 7. (For interpretation of the references to color in this figure legend, the reader is referred to the web version of this article.) 

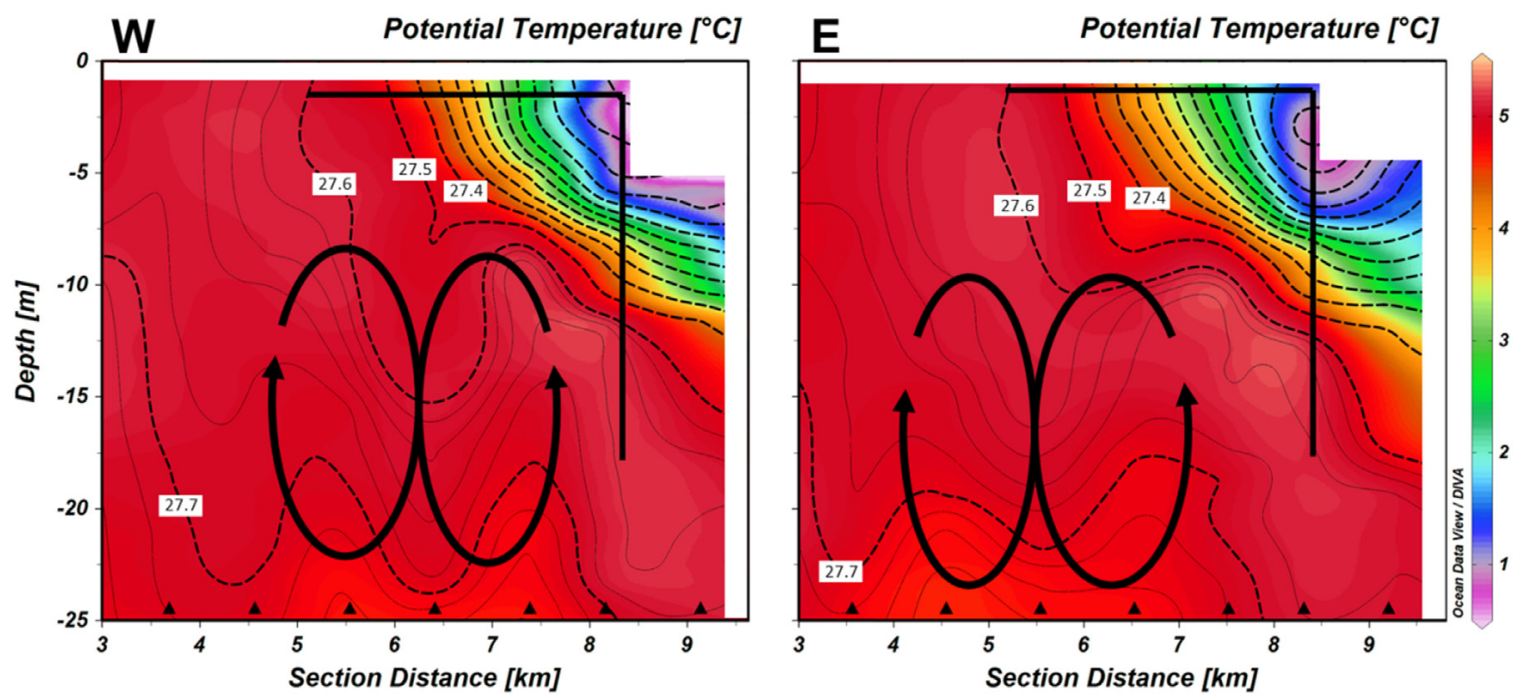

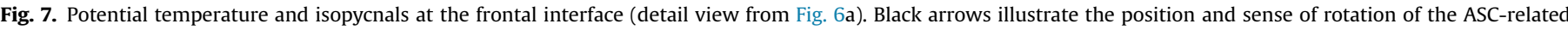

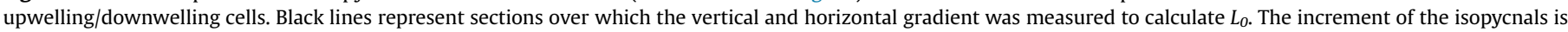
the same as in Fig. 6.

observations. Both sections cross the same ASC that has a crossfront width of about $3 \mathrm{~km}$.

However, the distance scale is quite sensitive to the assumed values of the parameters, making the estimate relatively rough.

Frontogenetic processes quickly affect the water column. Results of a numerical study (Thomas and Lee, 2005) which was conducted for an approximate $12 \mathrm{~m}$ Ekman depth, revealed the formation of upwelling and downwelling areas within 1-1.5 inertial periods (wind stress: $0.1 \mathrm{~N} \mathrm{~m}^{-2}$ and atmospheric buoyancy flux: $\left.6.3 \cdot 10^{-8} \mathrm{~m}^{2} \mathrm{~s}^{-3}\right)$. Considering the parameter regime of our study (dive site at $78.76^{\circ}$ ), 1-1.5 inertial periods correspond to 1218 h. During the 2013 Arctic campaign, down-front wind conditions were recorded on July 2nd, prior to the dive. These winds prevailed for only a short period of time, yet the duration exceeded $12 \mathrm{~h}$. In addition to that, horizontal density gradients at the meltwater front were significantly steeper than in the case of past investigations at the Kuroshio Current (Thomas and Lee, 2005; Clayton et al., 2014) or the Gulf Stream (Thomas et al., 2013). As a result, the horizontal Ekman buoyancy flux is particularly large, equivalent to several tens of thousands $\mathrm{W} \mathrm{m}^{-2}$ surface heat loss, whereas normal large storm events would lead to a maximum of $1000 \mathrm{~W} \mathrm{~m}^{-2}$ in open water, disregarding processes associated with sea ice. Thus, ASCs could cause high vertical velocities along a meltwater front

It is regrettable, that water velocity data were collected with a shipboard ADCP, yet data between the surface and $60 \mathrm{~m}$ water depth had to be neglected due to an uncorrectable error. As a consequence, potential vorticity (PV), which would have provided insights about the stability of the water column with respect to several types of instabilities, could not be computed.

\subsection{Biological response}

\subsubsection{Biogeochemical zones}

In both sections, a distinctive pattern of chlorophyll $a$ (chl. $a$ ), nitrate and oxygen saturation is recognizable (Fig. 8). High amounts of chl. $a$ go along with low nitrate concentrations and elevated oxygen saturation values and vice versa. Regarding this ratio, three different zones, each representing a specific manifestation of this ratio, can be identified.

The first zone will further be referred to as the "accumulation and subduction zone" (Fig. 8a: black rectangle). It comprises one of the most prominent features of the biogeochemical sections with an area of high chl. $a$ concentrations close to the surface at the meltwater interface at $x=4-5 \mathrm{~km}$. Here, chl. $a$ concentrations of up to $4-5 \mu g l^{-1}$ were observed (Fig. 8a). Nitrate was almost depleted in this layer, whereas the water was supersaturated with oxygen (120\%) (Fig. 8b, c). This zone extended deeper into the water column (to $\sim 20 \mathrm{~m}$ ) into depths where nitrate concentrations were 2 $4 \mu \mathrm{mol} \mathrm{l}^{-1}$ and chl. $a$ was $\sim 1-2 \mu \mathrm{g}^{-1}$. This oxygen supersaturated zone, located within the euphotic layer, follows the downward indentation of the isopycnals, and indicates ongoing phytoplankton growth.

Secondly, in the "low stratification zone" at $x=1-2 \mathrm{~km}$ (Fig. 8a: red rectangle), chlorophyll a concentrations of $1-1.5 \mu \mathrm{g} \mathrm{l}^{-1}$ were measured to the maximum dive depth of the vehicle of $50 \mathrm{~m}$. This is remarkable as the euphotic depth (ED) was measured to be at $27 \pm 7 \mathrm{~m}$ depth. However, reduced nitrate concentrations and elevated oxygen saturation values (Fig. 8b, c) indicate recent biological activity in this zone.

Oxygen saturation, nitrate and chlorophyll $a$ concentration illustrate another prominent feature of the sections across the meltwater front centered at $x=4 \mathrm{~km}$ and $8-9 \mathrm{~km}$ in section west and at $x=3 \mathrm{~km}$ and $8 \mathrm{~km}$ at section east; "dome-like" structures (Fig. 8a: blue rectangles) of high nitrate concentrations are present (Fig. 8b). These domes are $\sim 2 \mathrm{~km}$ wide and rise up to $30 \mathrm{~m}$ water depth. Compared to surface conditions, the domes are characterized by low chlorophyll $a$ and oxygen saturation values, but high nitrate concentrations. Within the domes, chlorophyll $a$ concentrations were below the detection limit and nitrate reached a maximum of $10-12 \mu \mathrm{mol} 1^{-1}$ which represents deep water concentrations (Bauerfeind et al., 2014). Oxygen saturation was reduced compared to water at the surface, but still reached $100 \%$. At the frontal interface, about $x=6 \mathrm{~km}$ and $0-20 \mathrm{~m}$ depth, the gradients in nitrate concentration and oxygen saturation appear to be strongly correlated to isopycnals. In contrast, this relation between isopycnals and biogeochemical parameters cannot be detected for the domes. The domes are clearly visible in the biogeochemical parameters, yet they cross the contour lines of the physical parameters.

The almost identical picture of the two sections in the hydrographic properties is also seen in the biogeochemical data. Except for the domes, the biogeochemical parameters correspond to the physical parameters. Although PAUL's data only reached down to $50 \mathrm{~m}$, we expect the structures to continue to some extent below.

Apart from the aforementioned parameters, the concentration 

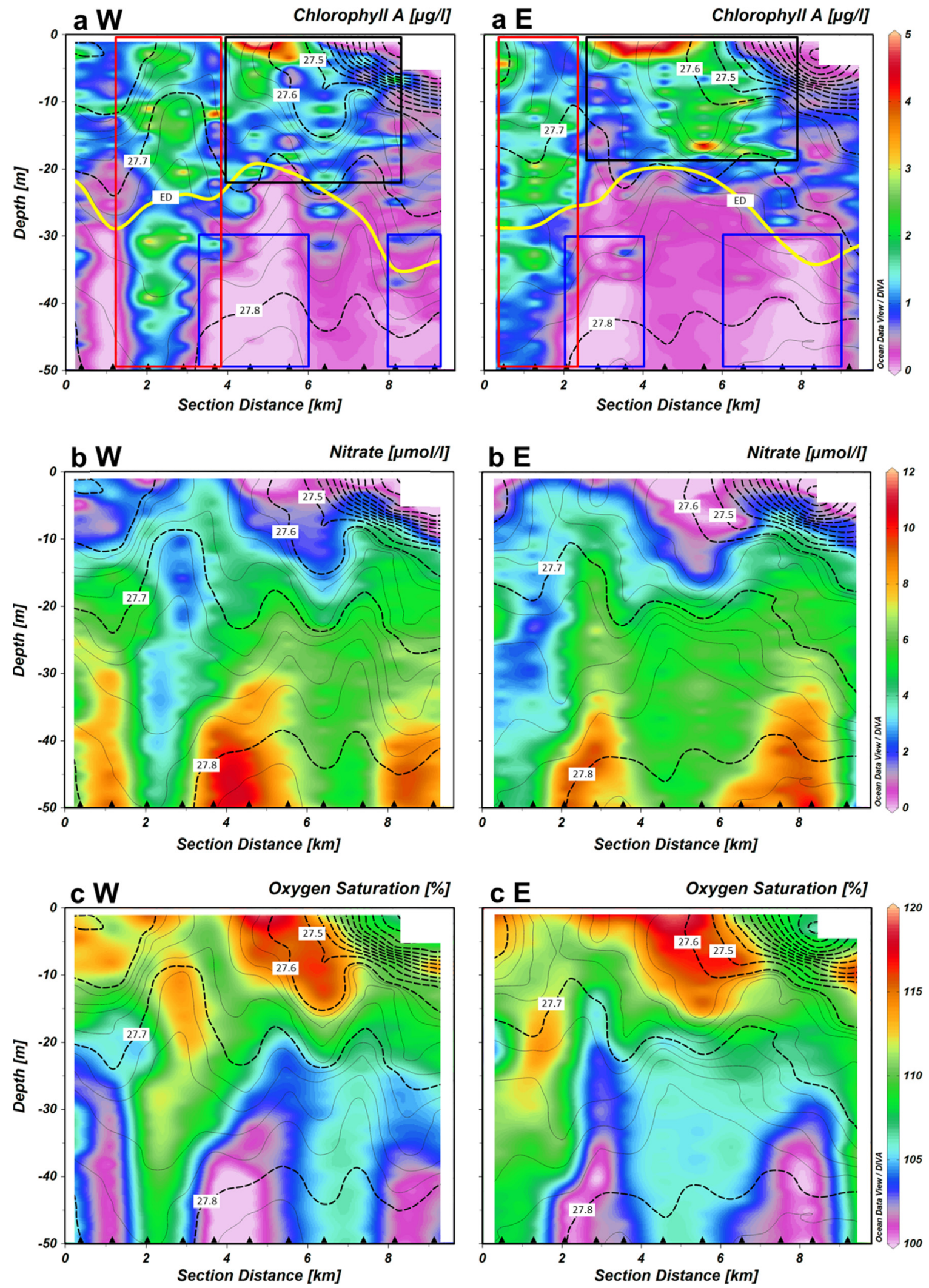

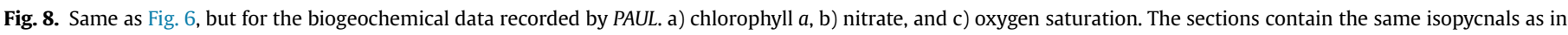

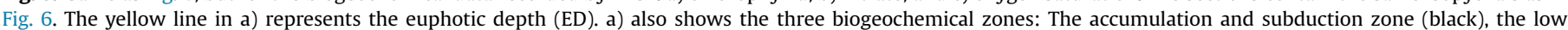

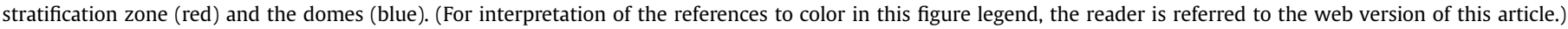

of colored dissolved organic matter $(\mathrm{CDOM})$ and $\mathrm{CO}_{2}$ were measured as well. However, CDOM data did not provide any information and $\mathrm{CO}_{2}$ data were neglected as the sensor's response time caused major concerns about the reliability of the data.

We now discuss the dynamics in these different zones in detail. 
3.3.1.1. Accumulation and subduction zone. Comparably high chlorophyll $a$ concentrations (4-5 $\mu \mathrm{g} \mathrm{l}^{-1}$ ) were found near the surface $(<5 \mathrm{~m})$ at the meltwater front, framed by the black rectangle (Fig. 8a). Below, also framed by the black rectangle, an area of elevated chlorophyll $a$ concentrations $\left(1-2 \mu \mathrm{g} \mathrm{l}^{-1}\right.$ ) extended to the base of the euphotic zone at $\sim 20 \mathrm{~m}$. Oxygen supersaturation in this zone indicates the presence of growing phytoplankton populations. The question remains how the high chlorophyll $a$ concentration at the surface developed. We exclude that this was caused by the input of nutrients due to the frontogenetic processes described before, as the time required for the development of an ice edge bloom is several days after the input of new nutrients into the surface layer (e.g. Mundy et al., 2009). Prior to the dive, there was about $12-18 \mathrm{~h}$ of wind conditions suitable for frontogenesis, which was too short for phytoplankton to build the high standing stock observed. A rough estimate, applying the Redfield ratio (C/ $\mathrm{N}=6.7$, Redfield et al., 1963; Sterner et al., 2008) and a C/Chl. $a$ ratio of 100-200 (Smith and Sakshaug, 1990), results in a nitrate requirement of $5-10 \mu \mathrm{mol}^{-1}$ to build up these chlorophyll $a$ concentrations. As the dive was conducted several weeks after the Arctic spring bloom (between March and May, e.g. Degerlund and Eilertsen, 2010) the maximum nitrate concentrations encountered in the upper $10 \mathrm{~m}$ of the study region at that time were between 0 and $3 \mu \mathrm{mol}^{-1}$. Therefore, although nitrate concentrations were not totally depleted, it is unlikely that phytoplankton had grown at that spot, with the most probable cause of the high chlorophyll $a$ concentrations being the product of recent accumulation processes at the meltwater interface.

Accumulation of plankton at frontal systems is a known feature which, besides physical processes, is also affected by the ability of growing phytoplankton to stay positively or neutrally buoyant (e.g. Smayda, 1970; Franks, 1992; Acuña et al., 2010; McManus and Woodson, 2012; Prairie et al., 2012; Arrieta et al., 2015). As a consequence, phytoplankton is not purely advected like a passive tracer, as positively buoyant organisms withstand the flow of water to a certain degree. This is the most probable scenario by which we can explain the vastly higher chlorophyll $a$ concentration at the surface of this zone.

One phytoplankton group that is known for its ability of buoyancy regulation is the colony forming Phaeocsytis sp. (Skreslet, 1988; Wang and Tang, 2010) which has become increasingly important in the phytoplankton community in Fram Strait during recent years (Nöthig et al., 2015). Unfortunately, the proposed scenario cannot be tested with the available data as PAUL's water samples were not analyzed with respect to plankton composition. However, qualitative analyses of plankton net samples from the upper $20 \mathrm{~m}$ after the dive revealed that colonies of Phaeocystis sp. dominated in the vicinity of the ice edge.

The deeper part of the accumulation and subduction zone (Fig. 8a: black rectangle) between 10 and $20 \mathrm{~m}$ depth shows moderate chlorophyll $a$ concentrations of $1-2 \mu \mathrm{gl}^{-1}$ and high oxygen saturation values of $115-120 \%$. We consider this part of the zone to be the result of a subduction process. Here, the downwelling branch of an ASC-related rotating cell affects the water column. The downward displaced density contour lines are consistent with an ongoing downward vertical motion on the denser side of the front, with phytoplankton being actively transported into deeper regions (Fig. 6a: $x=6 \mathrm{~km}, 15 \mathrm{~m}$ depth).

The existence of the accumulation and subduction zone and wind data give rise to the following scenario: The meltwater front stretched from east to west from July 1 st onwards (Fig. 3e). Assuming the front maintained its orientation on June 30th, on-front wind conditions dominated for $48 \mathrm{~h}$ (Fig. 3g). Due to surface Ekman transport, on-front wind conditions caused an intensification of the front as it was recorded by Merian in the evening of July 1st (Fig. 3f), and, at the same time, phytoplankton was accumulated along the frontal interface. In the morning of July 2nd, wind conditions turned to down-front eventually stimulating a frontogenetic ASC. Starting on July 2nd, the rotating cell of the ASC, situated at $x=7 \mathrm{~km}$ and $12-15 \mathrm{~m}$ water depth, partly eroded the phytoplankton accumulation from below and transported phytoplankton into deeper regions (subduction). Phytoplankton with stronger positive buoyancy would remain in the lower density surface layer as the water's density slightly increases upon subduction and isolation from diurnal heating and wave breaking induced bubble input. This could explain the apparent decoupling of the phytoplankton transport from the water flow.

However, phytoplankton distribution is also influenced by other factors such as the grazing by zooplankton. The described scenario, therefore, might not be the sole reason for the observed chlorophyll a distribution, but nevertheless could have a considerable influence.

3.3.1.2. Low stratification zone. With regard to the physical parameters, the low stratification zone (Fig. 8a: red rectangle) is characterized by isopycnals with extended vertical distance. This phenomenon had been detected before (see Johannessen et al. (1983), their Fig. 15, section X, at $x=18 \mathrm{~km}$ and 10-18 m depth), but the evolution of that feature had not been discussed. As observed during the AUV dive, chlorophyll $a$ has been submerged to at least $50 \mathrm{~m}$, well below the euphotic depth (ED) in this zone, meaning it was not formed at that depth and so must have encountered active vertical transport. The course of the isopycnals and submerged chlorophyll $a$ suggests that a downwelling event might be superimposed by weaker upwelling. Although a specific downwelling event could not be identified, it can be speculated that upwelling was caused by frontogenetic processes on July 2nd (see Frontogenesis). The upwelling event would have lasted over a shorter period than the potentially unidentified downwelling event and its impact remained limited to the uppermost meters - causing the isopycnals to move further apart.

Another option to explain this structure is the presence of a filament which was crossed by PAUL's dive. Filaments can be related to frontogenetic processes and high vorticity filaments can be associated to significant vertical water transports (Lapeyre and Klein, 2006; Legal et al., 2007). However, as PV values cannot be determined, this approach remains speculative.

3.3.1.3. Domes. Despite the fact that the domes (Fig. 8a: blue rectangles) appear to be indicative of individual upwelling events, measured nitrate concentrations in the domes are not unusual for this depth. Taking a nitrate concentration of $8 \mu \mathrm{mol} \mathrm{l}^{-1}$ to mark the domes, it can be seen that the tips of the domes reach up to $\sim 35-40$ m water depth (Fig. 8b). Previous years' AUV dives revealed similar nitrate concentrations at the same depth. Additionally, various other studies also reported comparable nitrate concentrations (e.g. $8 \mu \mathrm{mol} \mathrm{l}^{-1}$ nitrate in Smith et al., 1985, 1987: $50 \pm 15 \mathrm{~m}$ depth; Kattner and Becker, 1991: between 40 and $50 \mathrm{~m}$ depth, Bauerfeind et al., 2014: between 25 and $50 \mathrm{~m}$ depth). This makes the domes less exceptional than the space between them. Compared to the domes, the space between them features slightly increased oxygen saturation values and chlorophyll $a$ concentrations. Nitrate concentrations are reduced (Fig. 8b). This indicates that the water masses between the domes originated from the surface or at least from a layer within the euphotic zone.

We therefore suggest that one or more downwelling events formed the gaps between the domes. Thus, the domes are relics of the previously undisturbed stratification of the water column. 
Unfortunately, as for the low stratification zone, the specific event leading to this dome-like structure could not be identified.

\section{Conclusion}

Within the framework of this study, an AUV conducted physical and biogeochemical investigations at the meltwater front of a moving ice edge. Occupying two transects of $9 \mathrm{~km}$ length each, the vehicle collected data on salinity, temperature, density, oxygen saturation, irradiance, nitrate and chlorophyll $a$ concentrations between the surface and $50 \mathrm{~m}$ water depth. Using satellite and shipboard data, the results of the dive were put into a larger context and processes which might have caused the evolution of the observed structures are discussed.

The high resolution cross-front sections revealed a complex structure of the water column and three zones with different biogeochemical characteristics could be identified. The existence of at least one of these zones, the black framed accumulation and subduction zone (Fig. 8a) originated from a wind driven intensification of the meltwater front. With regard to this wind driven intensification, the main difference between previous studies and PAUL's investigations is the depth of the front. Previous field studies confirming the findings of Thomas and Lee (2005) were conducted at systems where the frontal structures were deeper than the Ekman layer (e.g. at the Kuroshio Current by Thomas and Lee (2005) or along the Gulf Stream by Thomas et al. (2013)). Therefore, the entire momentum of the wind affected the front in the form of the integrated Ekman transport. The herein described meltwater front only reached $15 \mathrm{~m}$ deep and the depth of the Ekman layer was estimated to be about $40 \mathrm{~m}$ during the down-front wind event on July 2 nd. As a consequence, only the momentum close to the surface is communicated to the front (Lee and Eriksen, 1996). The lack of water velocity data between the surface and $60 \mathrm{~m}$ water depth represented a major setback for this study. Measuring potential vorticity was identified as a major objective for future investigations. However, PAUL'S measurements represent the first observations of frontogenetic processes and associated vertical transports at a meltwater front.

In contrast to the accumulation and subduction zone, processes which formed the low stratification zone and the domes remained speculative. As PAUL's data provided just a short and small glimpse of the entire dynamics of the MIZ, the evolution of these structures could not be traced back to specific events.

Quantifying the impact of these processes on the plankton ecology of larger areas, maybe on the entire Fram Strait or MIZs in general, is not possible yet. With regard to wind driven frontogenesis, the depth of the front might also limit the ecological relevance of the process. The depth of the front might largely determine the depth over which the ASC penetrates i.e. a shallow front resulting in shallow ASCs. Frontogenetic upwelling and downwelling events might therefore be confined to the euphotic zone and the nutrient concentrations would remain unchanged, however, the ecological impact of frontogenesis at meltwater fronts needs to be addressed as a subject of future research efforts. In contrast, the low stratification zone has an ecological effect as water masses featuring clear signs of recently active photosynthetic processes are transported below the euphotic zone.

Thus, the major outcome of this study is.

a) the high resolution data showed the complexity of the water column's structure and they illustrated the variety of processes which act on different spatial and temporal scales and superimpose each other.

b) Wind driven frontogenetic processes and the associated vertical transports occur along the meltwater front although the frontal system is comparably shallow. c) Apart from the ice itself, the meltwater front represents an additional feature in the MIZ which is capable of stimulating vertical transports, potentially resulting in the ecological system benefitting from this additional process, which so far has been recognized inadequately.

The study emphasized the necessity for high resolution data. Clayton et al. (2014) pointed out that alternative observation methods, namely operations with specifically equipped AUVs, are required "to fully understand the bio-physical dynamics" at frontal systems.

\section{Acknowledgements}

The authors would like to thank Sascha Lehmenhecker and Jonas Hagemann for their technical work and support on AUV PAUL. We would like to thank Kristin Hardge and Kai-Uwe Ludwichowski (both AWI) for their help with processing PAUL's water samples. The achievements of Michael Klages, who initiated the entire AUV project at AWI in 2002, are gratefully acknowledged. We would like to express our deep sense of gratitude to the four anonymous reviewers and Eva-Maria Nöthig for their very helpful comments and to James Taylor who ensured the linguistic quality of the manuscript. Thanks are also due to all people involved in the Arctic cruise of Merian in June/July 2013 (MSM 29) - especially the ship's crew for excellent support and accommodation. Ship time was provided by the Deutsche Forschungsgemeinschaft (DFG). The financial support received through the Helmholtz Gemeinschaft (HGF), the HGF-Research Program PACES (Polar Regions and Coasts in the changing Earth System), and the Helmholtz Alliance ROBEX (Robotic Exploration of Extreme Environments, grant number: HA-304) is gratefully acknowledged. AUV operations were part of AWI's HAUSGARTEN project. AMSR-2 data were supplied by the GCOMW1 data providing service, Japan Aerospace Exploration Agency (JAXA).

Wind data were downloaded from the following MERRA-link: http://gdata1.sci.gsfc.nasa.gov/daac-bin/G3/gui.cgi?instance_ id=MERRA_HOUR_3D.

Data on sea-ice concentration were downloaded from:

http://www.iup.uni-bremen.de:8084/amsr2data/asi_daygrid_ swath/n3125/.

\section{References}

Acuña, J.L., López-Alvarez, M., Nogueira, E., González-Taboada, F., 2010. Diatom flotation at the onset of the spring phytoplankton bloom: an in situ experiment. Mar. Ecol. Prog. Ser. 400, 115-125. http://dx.doi.org/10.3354/meps08405.

Acker, J.G., Leptoukh, G., 2007. Online analysis enhances use of NASA earth science data. Eos, Trans. Am. Geophys. Union 88 (2), 14-17. http://dx.doi.org/10.1029/ 2007 EO020003.

Arrieta, J., Barreira, A., Tuval, I., 2015. Microscale patches of nonmotile phytoplankton. Phys. Rev. Lett. 114, 128102-1-128102-5. http://dx.doi.org/10.1103/ PhysRevLett.114.128102.

Bauerfeind, E., Nöthig, E.M., Beszczynska, A., Fahl, K., Kaleschke, L., Kreker, K., Klages, M., Soltwedel, S., Lorenzen, C., Wegner, J., 2009. Particle sedimentation patterns in the eastern Fram Strait during 2000-2005: Results from the Arctic Long-Term Observatory HAUSGARTEN. Deep-Sea Res Pt I 56 (9), 1471-1487. http://dx.doi.org/10.1016/j.dsr.2009.04.011.

Bauerfeind, E., Kattner, G., Ludwichowski, K.U., Nöthig, E.M., Sandhop, N., 2014. Inorganic nutrients measured on water bottle samples at HAUSGARTEN during POLARSTERN cruise ARK-XXIII/2. Pangaea . http://dx.doi.org/10.1594/ PANGAEA.834717.

Beszczynska-Möller, A., Fahrbach, E., Schauer, U., Hansen, E., 2012. Variability in Atlantic water temperature and transport at the entrance to the Arctic Ocean, 1997-2010. ICES J. Mar. Sci. 69 (5), 852-863. http://dx.doi.org/10.1093/icesjms/fss056.

Cherkasheva, A., Bracher, A., Melsheimer, C., Köberle, C., Gerdes, R., Nöthig, E.M., Bauerfeind, E., Boetius, A., 2014. Influence of the physical environment on polar phytoplankton blooms: a case study in the Fram Strait. J. Mar. Syst. 132, 196-207. http://dx.doi.org/10.1016/j.jmarsys.2013.11.008. 
Clayton, S., Nagai, T., Follows, M.J., 2014. Fine scale phytoplankton community structure across the Kuroshio Front. J. Plankton Res 36 (4), 1017-1030. http://dx. doi.org/10.1093/plankt/fbu020.

de Steur, L., Hansen, E., Gerdes, R., Karcher, M., Fahrbach, E., Holfort, J., 2009. Freshwater fluxes in the East Greenland Current: a decade of observations. Geophys Res Lett. 36 (23). http://dx.doi.org/10.1029/2009GL041278.

Degerlund, M., Eilertsen, H.C., 2010. Main species characteristics of phytoplankton spring blooms in NE Atlantic and Arctic waters (68-80 N). Estuaries Coasts 33 (2), 242-269. http://dx.doi.org/10.1007/s12237-009-9167-7.

Doney, S.C., 2006. Oceanography: plankton in a warmer world. Nature 444 (7120), 695-696. http://dx.doi.org/10.1038/444695a.

Edler, L., 1979. Recommendations on methods for marine biological studies in the Baltic Sea. Phytoplankton and chlorophyll. Balt. Mar. Biol. Publ. 5, 1-38.

Ekman, V.W., 1905. On the influence of the earth's rotation on ocean currents. Ark. Mat. Astron. Fys. 2, 1-53.

Engelsen, O., Hegseth, E.N., Hop, H., Hansen, E., Falk-Petersen, S., 2002. Spatial variability of chlorophyll-a in the Marginal Ice Zone of the Barents Sea, with relations to sea ice and oceanographic conditions. J. Mar. Syst. 35 (1), 79-97. http://dx.doi.org/10.1016/S0924-7963(02)00077-5.

Evans, C.A., O'Reily, J.E., Thomas, J.P., 1987. A handbook for measurement of chlorophyll a and primary production. Biological Investigations of Marine Antarctic Systems and Stocks (BIOMASS). vol. 8, pp. 1-114.

Franks, P.J., 1992. Phytoplankton blooms at fronts: patterns, scales, and physical forcing mechanisms. Rev. Aquat. Sci. 6 (2), 121-137.

Haine, T.W., Marshall, J., 1998. Gravitational, symmetric, and baroclinic instability of the ocean mixed layer. J. Phys. Oceanogr. 28 (4), 634-658. http://dx.doi.org/ 10.1175/1520-0485(1998)028<0634:GSABIO > 2.0.CO*2.

Johannessen, O.M., Johannessen, J.A., Morison, J., Farrelly, B.A., Svendsen, E.A.S. 1983. Oceanographic conditions in the marginal ice zone north of Svalbard in early fall 1979 with an emphasis on mesoscale processes. J. Geophys. Res.Oceans (1978-2012) 88 (C5), 2755-2769. http://dx.doi.org/10.1029/ JC088iC05p02755.

Kattner, G., Becker, H., 1991. Nutrients and organic nitrogenous compounds in the marginal ice zone of the Fram Strait. J. Mar. Syst. 2 (3), 385-394, doi: 10.1016/ 0924-7963(91)90043-T.

Kwok, R., Cunningham, G.F., Wensnahan, M., Rigor, I., Zwally, H.J., Yi, D., 2009. Thinning and volume loss of the Arctic Ocean sea ice cover: 2003-2008. J. Geophys. Res.-Oceans (1978-2012) 114 (C7). http://dx.doi.org/10.1029/ 2009JC005312.

Lapeyre, G., Klein, P., 2006. Impact of the small-scale elongated filaments on the oceanic vertical pump. J. Mar. Res. 64 (6), 835-851. http://dx.doi.org/10.1357/ 002224006779698369.

Lee, C.M., Eriksen, C.C., 1996. The subinertial momentum balance of the North Atlantic subtropical convergence zone. J. Phys. Oceanogr. 26 (9), 1690-1704, doi: 10.1175/1520-0485(1996)026 < 1690:TSMBOT > 2.0.CO; 2 .

Lee, C.M., Cole, S., Doble, M., Freitag, L., Hwang, P., Jayne, S., Jeffries, M., Krishfield, R., Maksym, T., Maslowski, W., 2012. Marginal Ice Zone (MIZ) Program: Science and Experiment Plan. (No. APL-UW-1201). Washington Univ. Seattle Applied Physics Lab.

Lee, Z., Weidemann, A., Kindle, J., Arnone, R., Carder, K.L., Davis, C., 2007. Euphotic zone depth: Its derivation and implication to ocean-color remote sensing. J. Geophys. Res.-Oceans (1978-2012) 112 (C3). http://dx.doi.org/10.1029/ 2006JC003802.

Legal, C., Klein, P., Treguier, A.M., Paillet, J., 2007. Diagnosis of the vertical motions in a mesoscale stirring region. J. Phys. Oceanogr. 37 (5), 1413-1424. http://dx. doi.org/10.1175/JPO3053.1.

McManus, M.A., Woodson, C.B., 2012. Plankton distribution and ocean dispersal. J. Exp. Biol. 215 (6), 1008-1016. http://dx.doi.org/10.1242/jeb.059014.

Mundy, C.J., Gosselin, M., Ehn, J., Gratton, Y., Rossnagel, A., Barber, D.G., Martin, J., Tremblay, J.E., Palmer, M., Arrigo, K.R., Darnis, G., Fortier, L., Else, B., Papakyriakou, T., 2009. Contribution of under-ice primary production to an ice-edge upwelling phytoplankton bloom in the Canadian Beaufort Sea. Geophys. Res. Lett. 36 (17). http://dx.doi.org/10.1029/2009GL038837.

Neumann, G., Pierson, W.J., 1966. Principles of Physical Oceanography 545. Prentice-Hall, Englewood Cliffs, NJ, p. 210, ISBN 10: 0137097417.

Niebauer, H.J., Alexander, V., 1985. Oceanographic frontal structure and biological production at an ice edge. Cont. Shelf Res. 4 (4), 367-388. http://dx.doi.org/ 10.1016/0278-4343(85)90001-9.

Nöthig, E.M., Bracher, A., Engel, A., Metfies, K., Niehoff, B., Peeken, I., Bauerfeind, E., Cherkasheva, A., Gäbler-Schwarz, S., Hardge, K., Kilias, E., Kraft, A., Kidane, Y.M., Lalande, C., Piontek, J., Thomisch, K., Wurst, M., 2015. Summertime plankton ecology in Fram Strait - a compilation of long- and short-term observations. Polar Res., 34. http://dx.doi.org/10.3402/polar.v34.23349.

Perrette, M., Yool, A., Quartly, G.D., Popova, E.E., 2011. Near-ubiquity of ice-edge blooms in the Arctic. Biogeosciences 8 (2), 515-524. http://dx.doi.org/10.5194/ bg-8-515-2011.
Prairie, J.C., Sutherland, K.R., Nickols, K.J., Kaltenberg, A.M., 2012. Biophysical interactions in the plankton: a cross-scale review. Limnol. Oceanogr.: Fluids Environ. 2 (1), 121-145. http://dx.doi.org/10.1215/21573689-1964713.

Redfield, A.C., Ketchum, B.H., Richards, F.A., 1963. The influence of organisms on the composition of seawater. In: Hill, M.N. (ed.) The Sea. Wiley, Interscience, New York, pp. 26-77.

Rienecker, M.M., Suarez, M.J., Gelaro, R., Todling, R., Bacmeister, J., Liu, E., Bosilovich M., Schubert, S., Takacs, L., Kim, G.K., Bloom, S., Chen, J., Collins, D., Conaty, A. da Silva, A., Gu, W., Joiner, J., Koster, R., Lucchesi, R., Molod, A., Owens, T., Pawson, S., Pegion, P., Redder, C.R., Reichle, R., Robertson, F.R., Ruddick, A.G., Sienkiewicz, M., Woollen, J., 2011. MERRA: NASA's modern-era retrospective analysis for research and applications. J. Clim. 24 (14), 3624-3648, doi: 10.1175/ JCLI-D-11-00015.1.

Schmidt, W., 1917. Wirkungen der ungeordneten Bewegung im Wasser der Meere und Seen. Ann. Hydrogr. Marit. Meteorol. 45, 367-381.

Skreslet, S., 1988. Buoyancy in Phaeocystis pouchetii (Hariot) Lagerheim. J. Exp. Mar. Biol. Ecol. 119 (22), 157-166. http://dx.doi.org/10.1016/0022-0981(88) 90230-4.

Smayda, T.J., 1970. The suspension and sinking of phytoplankton in the sea. Oceanogr. Mar. Biol. Ann. Rev. 8, 353-414.

Smith, S.L., Smith, W.O., Codispoti, L.A., Wilson, D.L., 1985. Biological observations in the marginal ice zone of the East Greenland Sea. J. Mar. Res 43 (3), 693-717. http://dx.doi.org/10.1357/002224085788440303.

Smith, W.O., Baumann, M.E., Wilson, D.L., Aletsee, L., 1987. Phytoplankton biomass and productivity in the marginal ice zone of the Fram Strait during summer 1984. J. Geophys. Res.-Oceans (1978-2012) 92 (C7), 6777-6786, doi: 10.1029/ JC092iC07p06777.

Smith, W.O., Sakshaug, E., 1990. Polar Phytoplankton (Chapter 9). Polar oceanography, Part B: Chemistry, Biology, and Geology. Academic Press Ltd, London, p. 477, ISBN: 0-12-653032-7.

Spreen, G., Kaleschke, L., Heygster, G., 2008. Sea ice remote sensing using AMSR-E 89-GHz channels. J. Geophys. Res.-Oceans (1978-2012) 113, C02S03. http://dx. doi.org/10.1029/2005JC003384.

Sterner, R.W., Andersen, T., Elser, J.J., Hessen, D.O., Hood, J.M., McCauley, E., Urabe, J., 2008. Scale-dependent carbon: nitrogen: phosphorus seston stoichiometry in marine and freshwaters. Limnol. Oceanogr. 53 (3), 1169-1180. http://dx.doi.org/ 10.4319/lo.2008.53.3.1169.

Thiede, J., Pfirman, S., Schenke, H.W., Reil, W., 1990. Bathymetry of Molloy Deep: Fram Strait between Svalbard and Greenland. Mar. Geophys. Res. 12 (3) 197-214. http://dx.doi.org/10.1007/BF02266713.

Thomas, L.N., Lee, C.M., 2005. Intensification of ocean fronts by down-front winds. J. Phys. Oceanogr. 35 (6), 1086-1102. http://dx.doi.org/10.1175/JPO2737.1.

Thomas, L.N., 2008. Formation of intrathermocline eddies at ocean fronts by winddriven destruction of potential vorticity. Dyn. Atmos. Oceans 45 (3), 252-273.

Thomas, L.N., Taylor, J.R., Ferrari, R., Joyce, T.M., 2013. Symmetric instability in the Gulf Stream. Deep-Sea Res. Pt II 91, 96-110. http://dx.doi.org/10.1016/j. dsr2.2013.02.025.

Wang, X., Tang, K.W., 2010. Buoyancy regulation in Phaeocystis globosa Scherffel colonies. Open. Mar. Biol. J. 4, 115-121.

Wassmann, P., Reigstad, M., 2011. Future Arctic Ocean seasonal ICE zones and implications for Pelagic-benthic coupling. Oceanography 24 (3), 220-231 〈http:/| hdl.handle net/10037/3910

Wenzhöfer, F., Asendorf, V., Bauerfeind, E., Bienhold, C., Hagemann, J., Hasemann, C., Hüttich, D., Janssen, F., Lalande, C., Lehmenhecker, S., Lochthofen, N., Nowald, N., Ratmeyer, V., Rehage, R., Reuter, R., Reuter, M., Schewe, I., Seiter, C., Soltwedel, T., Tardeck, F., Wulff, T., Zarrouk, M., 2014. HAUSGARTEN 2013 - Cruise No. MSM29 - June 23 - July 12, 2013 - Tromsø (Norway) - Tromsø (Norway), Berichte von DFG Senatskommision für Ozeanographie, Bremen. http://dx.doi. org/10.2312/cr msm29.

Wulff, T., Lehmenhecker, S., Bauerfeind, E., Hoge, U., Shurn, K., Klages, M., 2013. Biogeochemical research with an Autonomous Underwater Vehicle: Payload structure and arctic operations. In OCEANS-Bergen, 2013 MTS/IEEE. IEEE, pp. 110. http://dx.doi.org/10.1109/OCEANS-Bergen.2013.6608043.

Wulff, U., Wulff, T., 2015. Correcting Navigation Data of Shallow-Diving AUV in Arctic. Sea Technol. 56 (3), 27-30.

Zhang, Y., Bellingham, J.G., Ryan, J.P., Kieft, B., Stanway, M.J., 2013. Two-dimensional mapping and tracking of a coastal upwelling front by an autonomous underwater vehicle. In Oceans-San Diego. IEEE, pp. 1-4

Zhang, Y., Bellingham, J.G., Ryan, J.P., Godin, M.A., 2015. Evolution of a physical and biological front from upwelling to relaxation. Cont. Shelf Res. 108, 55-64. http: //dx.doi.org/10.1016/j.csr.2015.08.005. 